\title{
Apeksifikasi dengan mineral trioxide aggregate dan perawatan intracoronal bleaching pada gigi insisivus sentralis kiri maksila non vital diskolorasi
}

\author{
I. Inajati* dan Raphael Tri Endra Untara** \\ *Polrestabes Semarang, Semarang, Jawa Tengah, Indonesia \\ **Departemen Konservasi Gigi, Fakultas Kedokteran Gigi, Universitas Gadjah Mada, Yogyakarta, Indonesia \\ *JI Dr. Sutomo No 19, Semarang, Jawa Tengah, Indonesia; e-mail: inajatiarifin@gmail.com
}

Submisi: 11 September 2015; Penerimaan: 1 Juni 2016

\begin{abstract}
ABSTRAK
Gigi anterior rahang atas pada anak-anak maupun dewasa sering mengalami trauma. Akibatnya pulpa gigi yang akarnya belum terbentuk sempurna akan mengalami nekrosis, dan penutupan apeks terhenti yang menyebabkan apeks lebar dan terbuka. Apeks yang terbuka dapat diatasi dengan perawatan apeksifikasi. Mineral Trioxide Aggregate (MTA) adalah bahan pilihan terbaik yang dipakai sebagai bahan apeksifikasi untuk pembentukan apical barrier. Tujuan laporan kasus ini adalah untuk melaporkan keberhasilan penutupan apikal dengan menggunakan MTA pada gigi permanen insisivus sentralis kiri maksila non vital dengan apikal yang terbuka karena trauma. Pasien laki-laki usia 20 tahun dengan keluhan gigi depan atas kiri patah dan berubah warna. Kejadian trauma sejak usia 10 tahun karena jatuh dan terbentur lantai. Pemeriksaan klinis gigi non vital dengan fraktur Ellis kelas IV disertai apeks terbuka lebar dan diskolorasi. Pada gambaran radiografis menunjukkan apeks yang terbuka lebar dengan saluran akar besar serta terdapat radiolusensi periapikal. Perawatan yang dilakukan adalah apeksifikasi dengan MTA dilanjutkan obturasi dengan gutta percha dan sealer AH 26. Setelah seminggu kemudian dilakukan intracoronal bleaching dengan aplikasi sodium perborat dan hidrogen peroksida $30 \%$. Sebelum perawatan, gigi berwarna kecoklatan (C4) setelah dilakukan perawatan menjadi warna putih kekuningan (B2). Seminggu setelah perawatan bleaching selesai kemudian dilakukan pemasangan pasak fiber, dilanjutkan dengan restorasi resin komposit kavitas kelas IV. Kontrol 2 minggu kemudian tidak menunjukkan adanya kelainan. Kesimpulan hasil perawatan apeksifikasi dengan MTA dapat mempercepat waktu perawatan dengan terbentuknya barier apikal yang merangsang penyembuhan dan dapat dilanjutkan dengan obturasi dengan gutta percha, kemudian dilakukan bleaching intracoronal bleaching dilanjutkan dengan restorasi akhir.
\end{abstract}

Kata kunci: apeksifikasi, diskolorasi, intracoronal bleaching, MTA

\begin{abstract}
Affecification with mineral trioxide aggregate and care of intracoronal bleaching on the non vital discoloration maxillary left central incisor. Maxillary anterior teeth in children and adults often experience trauma. This later makes the dental pulp roots that are not completely formed face the necrosis and apical closure stop later causing the apex wide and open. The opened apex can be coped with the care of affecification. Mineral Trioxide Aggregate (MTA) is the best material of affecification used for the formation of apical barrier. The purpose of this case report was to report the achievement of the apical sealing using MTA in the non-vital permanent maxillary left central incisor with the opened apical due to the trauma. The complaints of male patients aged 20 years was about the broken and discoloured left upper front teeth and becomes a traumatic event since the age of 10 years due to a fall and hit the cement floor. A clinical examination of non-vital teeth used the fracture Ellis IV class with wide open apex and discoloration. The radiographic image showed a widely opened apex with large root canal and there was a periapical radiolucency. The treatment given was affecification with MTA followed obturation with gutta-percha and sealer AH 26. In the following week it was continued with intracoronal bleaching with the application of sodium perborate and $30 \%$ hydrogen peroxide. Before treatment, the teeth were brownish (C4) and after treatment it turned into yellowish white (B2). A week after the bleaching treatment was completed and the installation of fibre post was done, followed by giving the composite resin restorations class IV cavity. The 2-week control later showed no abnormalities. In conclusion, the affecification treatment with MTA can accelerate treatment with the formation of apical barrier that stimulates the healing and may be followed by obturation with guttap percha followed by doing intracoronal bleaching and final restoration.
\end{abstract}

Keywords: affecification, discoloration, intracoronal bleaching, MTA

\section{PENDAHULUAN}

Gigi anterior rahang atas pada anak anak atau dewasa, paling sering mengalami trauma, dan bila terjadi trauma pada saat apeks gigi belum terbentuk sempurna, maka pulpa dapat menjadi nekrotik, penutupan apeks akan terhenti yang menyebabkan apeks gigi terbuka. 
Pulpa nekrosis dengan kelainan periapikal dan apeks terbuka lebar, sering dianggap tidak dapat dilakukan dengan perawatan endodontik konvensional, sehingga diperlukan tindakan bedah bahkan mungkin dilakukan pencabutan. Namun sebenarnya kondisi semacam itu dapat dipertahankan, banyak bukti kasus dengan kelainan periapeks baik dengan apeks tertutup maupun apeks terbuka yang disertai dengan abses, granuloma, bahkan kista sekalipun dapat dilakukan perawatan endodontik secara konvensional dengan keberhasilan baik. ${ }^{1}$ Pembentukan akar yang tidak sempurna dan belum terjadi penutupan apikal dapat menyebabkan saluran akar menjadi lebar dengan dinding yang tipis sehingga gigi rapuh.,2,3

Salah satu perawatan endodontik untuk merawat gigi dengan apeks terbuka dengan pulpa nekrosis adalah apeksifikasi. ${ }^{4,5}$ Apeksifikasi adalah cara untuk mengisi dan memacu perkembangan apikal gigi yang imatur non vital dengan pembentukan osteosementum atau jaringan menyerupai tulang lainnya yang bertujuan menginduksi penutupan sepertiga apikal saluran akar atau pembentukan suatu apical calcific barrier pada apikal sehingga pengisian saluran akar dapat dilakukan secara hermetic seal. ${ }^{6}$ Calcific barier diperlukan untuk mencegah ekstruksi semen dan guta perca ke arah periapikal pada saat dilakukan obturasi.

Apeksifikasi dapat dilakukan pada gigi anak anak maupun dewasa. ${ }^{7}$ Masalah utama dalam perawatan apeksifikasi adalah sulitnya mencapai penutupan daerah apikal dengan baik. Tujuan apeksifikasi untuk mencapai penutupan apeks melalui pembentukan barier kalsifikasi di ujung apeks sehingga dapat dilakukan obturasi saluran akar dengan baik dan untuk menjamin keberhasilan apeksifikasi, saluran akar harus bebas infeksi. ${ }^{5}$

Bahan yang sering digunakan untuk apeksifikasi adalah Kalsium hidroksida $\left(\mathrm{Ca}(\mathrm{OH})_{2}\right)$, karena kemampuannya merangsang jaringan keras di sekitar apeks, sebagai apical calcific barrier. ${ }^{8}$ Penggunaan sebagai medikasi saluran akar memiliki potensi untuk menyembuhkan kelainan periapeks karena bersifat bakterisid dan dapat bertahan lama dalam saluran akar. Kelemahannya yaitu diperlukan beberapa kali kunjungan dan membutuhkan waktu yang cukup lama, sehingga membutuhkan kerjasama pasien untuk datang dan melakukan perawatan terkadang mencapai 5 sampai 54 bulan dengan penggantian pasta kalsium hidroksida yang dilakukan tiap 3 bulan, mudah terjadi fraktur pada servikal gigi karena struktur jaringan keras gigi yang rapuh dengan dinding saluran akar yang tipis. .,9,10 $^{-10}$

Mineral trioxide aggregate (MTA) sebagai bahan pilihan alternatif yang tepat selain kalsium hidroksida. MTA ditemukan oleh Dr.Torabinejad di Loma Linda University pada tahun 1983. Bahan ini berbentuk bubuk yang terdiri dari partikel partikel halus hidrofilik yang komponen utama adalah tricalcium silicate, tricalcium aluminate, tricalcium oxide, silicate oxide dan bersifat basa kuat dengan pH awal 10,2 dan akan menjadi 12,5 yang mengeras dalam 3-4 jam setelah pencampuran., ${ }^{5,11,12}$ Kekuatan MTA terhadap tekanan akan meningkat sampai 21 hari dalam lingkungan yang lembab. ${ }^{12}$ Dalam tahun 1999, Torabinejad dan Chivan mengemukakan penggunaan MTA sebagai sumbat apikal (apical plug) yaitu barier apikal buatan yang dapat secara cepat menutup apeks yang masih terbuka, sehingga saluran akar dapat langsung dilakukan obturasi dan restorasi tetap. ${ }^{4}$ MTA dapat menciptakan suasana anti bakteri, anti jamur dalam lingkungan alkali dan mempunyai kemampuan untuk membentuk hidroksiapatit di atas permukaan serta menciptakan biologic seal. ${ }^{13,14}$ Dengan demikian dapat mengurangi jumlah kunjungan bahkan dapat dilakukan hanya dalam beberapa kali kunjungan saja, sehingga dapat mengurangi resiko terjadinya fraktur gigi selama perawatan. ${ }^{4,9}$ Penggunaan MTA untuk apeksifikasi hasilnya lebih pasti dan mempersingkat waktu perawatan dengan hasil yang lebih memuaskan. ${ }^{15,16}$

Tujuan penulisan artikel ini untuk memaparkan kasus apeksifikasi dengan menggunakan MTA pada gigi permanen insisivus sentralis kiri maksila non vital yang berubah warna dengan apikal yang terbuka lebar yang disebabkan oleh trauma. Naskah ini telah mendapatkan persetujuan dari pasien untuk dilakukan publikasi.

\section{METODE}

Pasien laki laki, usia 20 tahun datang ke Bagian Konservasi RSGM Fakultas Kedokteran Gigi Universitas Gadjah Mada, atas kehendak 
sendiri ingin merawat gigi depan yang patah serta berubah warna. Gigi depan patah karena jatuh dari sepeda dan terbentur lantai semen pada usia 10 tahun. Gigi tersebut belum pernah dilakukan perawatan. Pasien saat ini mengeluhkan rasa tidak nyaman dan kurang percaya diri dengan keadaan tersebut serta ingin segera dirawat.

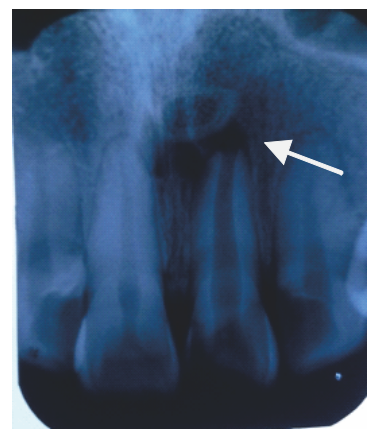

Gambar 1. Foto radiografi gigi 21 tampak radiolusen pada ujung akar gigi

Pemeriksaan objektif didapatkan gigi insisivus sentralis kiri (21) terdapat fraktur mahkota sepertiga yang melibatkan email, dentin dengan pulpa yang terbuka (Gambar 1). Tes perkusi, palpasi dan vitalitas negatif. Pada pemeriksaan radiografis nampak saluran akar dengan apeks yang terbuka dengan kamar pulpa yang besar serta terdapat radiolusensi periapikal. Gigi mengalami diskolorasi (Gambar 2). dengan warna kecoklatan (C4). Rencana perawatan terdiri dari perawatan apeksifikasi dengan MTA, dilanjutkan dengan obturasi gutta percha, pemutihan gigi (bleaching) intracoronal menggunakan sodium perborat dan hidrogen peroksida $30 \%$ kemudian dilakukan tumpatan klas IV resin komposit. Prognosis kasus ini baik, karena pasien dapat diajak kerjasama dan kebersihan mulut yang terjaga.

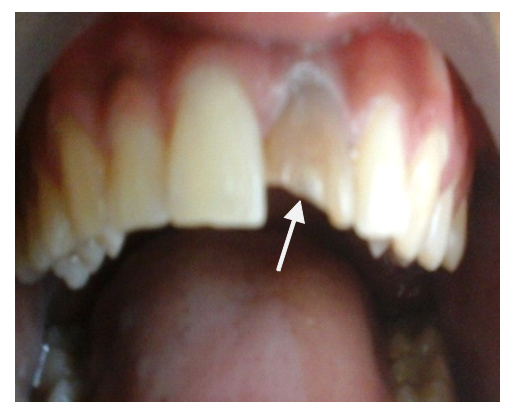

Gambar 2. Foto klinis gigi 21 yang mengalami perubahan warna kecoklat coklatan
Pada kunjungan pertama (Rabu, 5 November 2014), dilakukan pembuatan informed consent. Saat perawatan, dilakukan isolasi daerah kerja dengan pemasangan isolator karet dan saliva ejector. Selanjutnya kamar pulpa diirigasi dengan larutan salin untuk membuang semua debris dan jaringan nekrotik. Dilanjutkan dengan eksplorasi saluran akar dengan menggunakan K-file \#80 dengan panjang estimasi yang dihitung dari radiografis didapat panjang estimasi $21 \mathrm{~mm}$. Selanjutnya dilakukan pengukuran panjang kerja dengan apex locator (Sybron endo) didapat panjang kerja $20 \mathrm{~mm}$ yang sudah dikurangi $1 \mathrm{~mm}$ dari apikal, kemudiaan panjang kerja dikonfirmasi dengan foto radiografis (Gambar 3 dan 4).
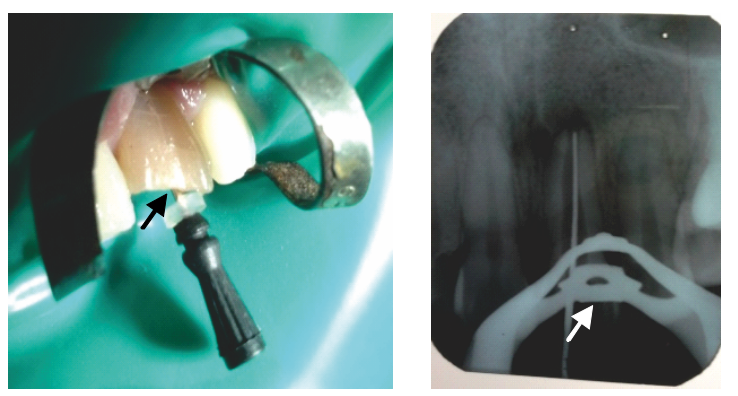

Gambar 3. Foto klinis panjang kerja gigi 21 Setelah dilakukan preparasi biomekanik

Gambar 4. Foto radiografis panjang kerja gigi 21 setelah dilakukan preparasi biomekanik

Preparasi biomekanik dilakukan menggunakan headstrome file \#80 dengan gerakan pull stroke dan disertai irigasi saluran akar menggunakan larutan salin sebanyak $2 \mathrm{ml}$ kemudian setelah selesai preparasi saluran akar, dilakukan dengan irigasi ulang dengan salin sebanyak $2 \mathrm{ml}$ dan terakhir digenangi dengan larutan klorhexidine diglukonat $2 \%$ selanjutnya saluran akar dikeringkan dengan paper point steril. Sterilisasi saluran akar dengan pasta kalsium hidroksida $\left(\mathrm{Ca}(\mathrm{OH})_{2}\right)$ ditambah larutan salin kemudian kavitas ditutup sementara dengan cavit.

Kontrol 1 minggu kemudian hasil pemeriksaan subjektif dan objektif tidak ada keluhan pada gigi 21. Selanjutnya daerah kerja diisolasi dengan pemasangan isolator karet dan saliva ejector kemudian tumpatan sementara dibuang. $\mathrm{Ca}(\mathrm{OH})_{2}$ dibersihkan dari saluran akar dengan bantuan K-file\# 80 lalu diirigasi dengan salin sebanyak 2 ml. Saluran akar dikeringkan dengan paper point 
steril. MTA dipersiapkan pada wadah stainless steel. Serbuk MTA dan larutan saline dicampur dan diaduk kemudian dimasukkan ke dalam saluran akar menggunakan MAP (Micro Apical Placement) sepanjang $5 \mathrm{~mm}$ ke arah apikal dan dipadatkan dengan finger plugger yang sudah dipasang stopper. Selanjutnya dilakukan pengambilan gambar radiografis setelah aplikasi MTA dalam saluran akar untuk konfirmasi pengisian MTA (Gambar 5). Kapas lembab yang telah dibasahi akuades dimasukkan ke dalam saluran akar kemudian kavitas ditutup dengan tumpatan sementara. Isolator karet dan saliva ejector dilepas. Pasien diinstruksikan untuk melakukan kontrol lagi seminggu kemudian.

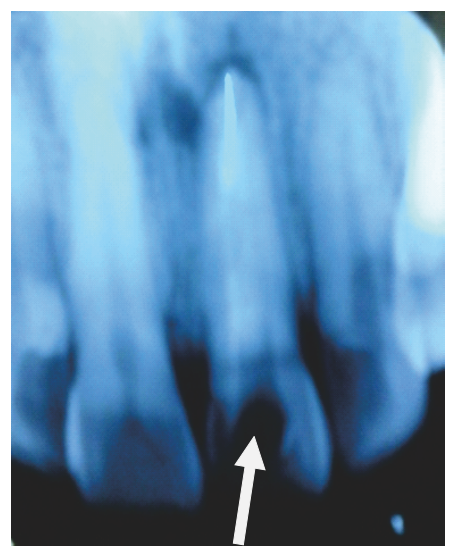

Gambar 5. Gigi 21setelah dilakukan pengisian dengan MTA

Seminggu kemudian (Jumat, 21 November), dilakukan kontrol tidak ada keluhan dan gambaran radiografi tidak ada kelainan. Selanjutnya dilakukan kontrol sampai 6 bulan.

Enam bulan kemudian, Rabu 6 Mei 2015 perawatan dilanjutkan isolasi daerah kerja dengan pemasangan isolator karet saliva ejector dan cotton roll. Tumpatan sementara dan kapas diambil dari kavitas. Selanjutnya dilakukan persiapan obturasi dengan gutta percha disterilkan menggunankan $\mathrm{NaOCL} 2,5 \%$ selama 1 menit kemudian dibilas dengan alkohol $70 \%$ selama 1 menit dan dikeringkan. Saluran akar diirigasi dengan larutan salin, kemudian disinfeksi dengan chlorhexidine digluconate $2 \%$ selama 1 menit dan dikeringkan dengan paper point. Gutta percha dengan ukuran no 80 dicobakan ke dalam saluran akar hingga menyentuh koronal MTA, kemudian dilakukan pengambilan radiografis (Gambar 6), untuk konfirmasi kedudukannya. Pengisian saluran akar menggunakan teknik kondensasi lateral yang dengan sealer $\mathrm{AH} 26$, dimasukkan ke dalam saluran akar dengan menggunakan lentulo yang ditandai dengan rubber stop sesuai panjang kerja dan diputar dengan handpiece lowspeed sehingga sealer menempel pada dinding saluran akar, kemudian gutta percha utama ( no 80 ) panjang 16 $\mathrm{mm}$ diolesi sealer sepertiga apikal dan dimasukkan ke dalam saluran akar dengan panjang $16 \mathrm{~mm}$. Spreader dimasukkan di antara gutta percha dan dinding saluran akar kemudian ditekan ke arah apikal. Setelah itu spreader dikeluarkan sehingga tersedia ruangan untuk diisi dengan gutta percha tambahan. Spreader ditekan kembali ke apikal sampai penuh. Setelah penuh, gutta percha dipotong sebatas orifis dengan heat plugger yang dipanaskan dan ditekan dengan tekanan ringan. Kemudian ditutup dengan cavit. Isolator karet dan saliva ejector dilepas. Pasien diinstruksikan untuk kembali seminggu.

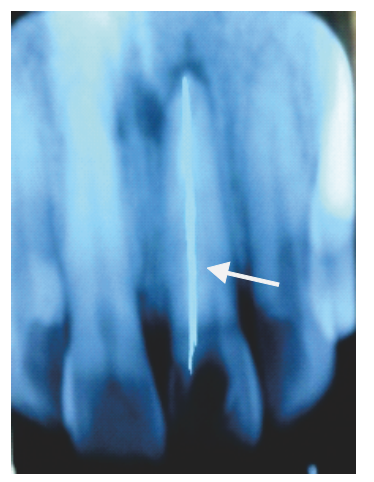

Gambar 6. Foto radiografis pengisian gutta percha pada gigi 21

Pada kunjungan berikutnya (Rabu, 13 Mei 2015), dilakukan pemeriksaan subjektif dan objektif. Pemeriksaan tidak menunjukkan kelainan. Sebelum dilakukan bleaching dilakukan pencatatan warna awal dengan shade guide warna kecoklatan (C4). Dilakukan isolasi dengan isolator karet dan saliva ejector. Tumpatan sementara dibuka dengan bur intan bulat gutta percha dikurangi $2 \mathrm{~mm}$ ke arah apikal dari orifis, kamar pulpa dibersihkan, kemudian dentin bagian labial dalam kamar pulpa dikurangi $0,5 \mathrm{~mm}$ dengan bur kecepatan rendah. 
Daerah kamar pulpa diberi conditioner selama 15 detik, cuci dengan akudes, dikeringkan dengan perlahan. Daerah orifis ditutup dengan semen ionomer kaca setebal $1 \mathrm{~mm}$, kemudian dilakukan pengambilan radiografis, untuk memastikan seluruh permukaan kamar pulpa sudah tertutup dengan semen ionomer kaca. Kamar pulpa dibersihkan dengan alkohol $70 \%$, kemudian dibilas dengan air dan dikeringkan. Pasta campuran sodium perborat dan hidrogen peroxida $30 \%$ diletakkan pada kamar pulpa, ditekan dengan kapas ke arah dinding labial kemudian ditutup dengan tumpatan sementara dan semen ionomer kaca. Isolator karet dan saliva ejector dilepas. Pasien diintruksikan untuk melihat perkembangan perubahan warna gigi setiap pagi, dan 3-7 hari dianjurkan untuk kembali.

Pada kunjungan berikut (Kamis, 21 Mei 2015), dilakukan kembali pemeriksaan subjektif dan objektif. Pada pemeriksaan subjektif dan objektif tidak ditemukan kelainan dan didapatkan warna B3. Tindakan intracoronal bleaching diulangi lagi. Dilakukan isolasi dengan isolator karet dan saliva ejector. Tumpatan sementara dibuka dengan bur intan bulat. Kamar pulpa dibersihkan dengan irigasi menggunakan salin kemudian dikeringkan. Pasta campuran sodium perborat dan hidrogen peroksida $30 \%$ diletakkan di dalam kamar pulpa, ditekan dengan kapas ke arah dinding labial, kemudian ditutup dengan tumpatan sementara dan semen ionomer kaca. Isolator karet dan saliva ejector dilepas. Pasien diinstruksikan untuk kembali 7 hari kemudian.

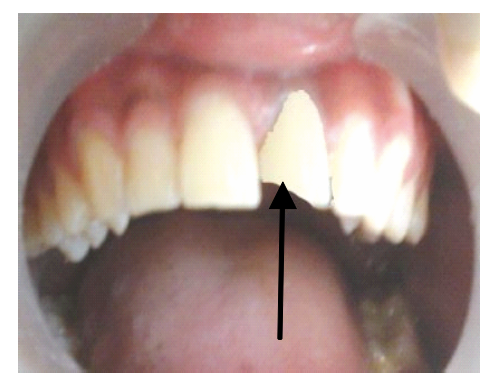

Gambar 7. Gigi 21 Setelah dilakukan bleaching

Setelah 7 hari pasien kembali dan dilakukan pemeriksaan warna gigi 11 sama warna gigi
21 dengan warna B2 (Gambar71). Selanjutnya dilakukan preparasi saluran pasak. Menentukan panjang pasak dan Peeso reamer dengan tracing pada radiografis, didapat panjang pasak $16 \mathrm{~mm}$, pasak fiber yang dipakai warna hijau. Membuang gutta percha sesuai dengan panjang pasak yaitu 16 $\mathrm{mm}$, menggunakan Gates Glidden Drill, kemudian dilanjutkan dengan preparasi menggunakan Peeso reamer, dilanjutkan dengan precission drill untuk pasak fiber warna hijau. Pasak fiber dicobakan ke dalam saluran pasak, kemudian konfirmasi dengan radiografis. Pasak fiber dikeluarkan dan diolesi silan dan dibiarkan mengering. Saluran pasak diirigasi dengan larutan aquadest steril, kemudian dikeringkan dengan paper point. Pemberian etsa pada seluruh permukaan kavitas dan saluran pasak, diamkan selama 15 detik, kemudian bilas dengan larutan aquadest dan dikondisikan lembab dengan cotton pellet dan paper point lembab. Pemberian bonding menggunakan microbrush pada seluruh kavitas dan saluran pasak yang telah dietsa. Tunggu 30 detik, kemudian mengambil kelebihan XP Bond (Dentsply) dalam saluran pasak menggunakan paper point dilanjutkan dengan menyemprotkan angin perlahan lahan di sekitar kavitas, lalu diaktivasi sinar selama 20 detik. Semen resin dipersiapkan, diaduk sesuai petunjuk pabrik dan dimasukkan ke dalam saluran pasak dengan lentulo, pasak fiber diolesi semen resin dan dimasukkan ke dalam saluran akar perlahan dengan gerakan memutar ke dalam saluran pasak. Tahan pasak fiber sampai semen resin mengeras sekitar 4-5 menit. Dilakukan pemotongan pasak fiber menggunakan diamond bur, duapertiga panjang mahkota klinis. Restorasi dilanjutkan dengan bagian palatal dengan resin komposit. Permukaan dalam pulpa diolesi bonding generasi ke-7, kemudian dihembuskan dengan air syringe selama 5 detik, kemudian disinar 20 detik. Orifis diisi dengan resin komposit, kemudian disinar dan dibentuk serupa dengan gigi 11, kemudian dilakukan finishing dengan fine finishing diamond bur, dan polishing dengan opti shine. Diinstruksikan untuk kontrol seminggu kemudian.

Setelah seminggu (Senin, 1 Juni 2015), dilakukan pemeriksaan subjektif dan objektif, tidak ada keluhan. 


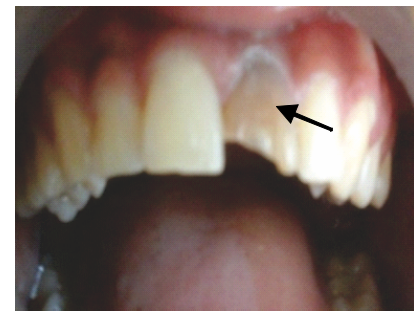

(A)

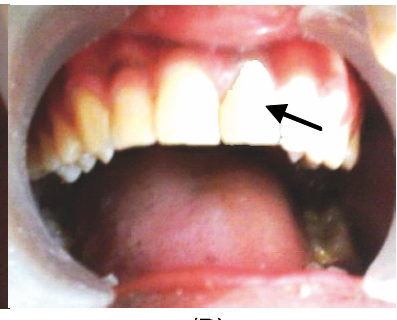

(B)
Gambar 9. Setelah dilakukan pemasangan fiber dan restorasi resin komposit: (A) Foto sebelum perawatan pada gigi 21 ; (B) Foto setelah dilakukan perawatan pada gigi 21

\section{PEMBAHASAN}

Komplikasi akibat trauma yang terjadi pada gigi insisivus rahang atas saat pasien berumur 10 tahun, mengakibatkan pulpa nekrosis sehingga pertumbuhan akar terhenti yang menyebabkan apeks tetap terbuka sedangkan pertumbuhan apeks selesai terbentuk 3 tahun setelah gigi erupsi. ${ }^{7}$ Gigi nekrosisi dengan apeks terbuka mempunyai dinding saluran akar yang tipis dan mudah pecah sehingga agak menyulitkan saat preparasi dan pengisian saluran akar. ${ }^{4,5}$

Oleh karena itu pada kasus ini harus dilakukan apeksifikasi terlebih dahulu untuk memperoleh penutupan apeks melalui pembentukan barier kalsifikasi di ujung apeks. Pengukuran panjang kerja pada gigi dengan apeks terbuka harus diukur lebih pendek $2 \mathrm{~mm}$ dari ujung apeks, agar tidak melukai jaringan periapikal yang dapat merusak barier apikal. ${ }^{5}$ Penting diperhatikan bahwa sebelum meletakkan bahan apeksifikasi saluran akar harus bersih dan bebas infeksi.

Apeksifikasi konvensional dengan bahan kalsium hidroksida banyak mengalami kendala sehingga berbagai bahan telah diusulkan sebagai alternatif. Pada tahun 1999, Torabinejad dan Chivian merekomendasikan penggunaan MTA yang bertindak sebagai apical plug yang mengiinduksi pembentukan apical calcific barier dan proses penyembuhan sehingga proses pengisan saluran akar dapat lebih cepat dilakukan, mencegah fraktur dan dapat memberikan keuntungan dalam mengurangi jumlah paparan radiografis dan meningkatkan kooperatif pasien. ${ }^{17}$ MTA merupakan bahan berbentuk serbuk aggregate yang mengandung mineral oksida. ${ }^{18}$
Penggunaan MTA untuk apeksifikasi memiliki kelebihan dapat mempersingkat periode waktu kunjungan dengan hanya sekali kunjungan, ${ }^{19}$ biokompatibel, ${ }^{20}$ dapat menginduksi pembentukan jaringan keras $^{21,22}$ dan membentuk apical plug yang baik. ${ }^{23}$ Prosedur apeksifikasi diawali dengan debridemen kemomekanis dan aplikasi medikamen intrakanal. Sjogren dkk., menyatakan bahwa medikamen intracanal selama 7 hari dengan kalsium hidroksida sangat efektif membunuh mikroorganisme saluran akar. ${ }^{24}$ Apeksifikasi dengan bahan MTA dapat merangasang pembentukan calcific barier dan penyembuhan apikal sehingga terbentuknya kerapatan apikal serta memungkinkan penempatan restorasi dalam saluran akar dapat segera dilakukan dengan minimal aplikasi MTA 24 jam sehingga dapat mencegah fraktur.

Apeksifikasi dapat mengurangi resiko fraktur akar dan mahkota antar kunjungan dengan saluran akar yang tipis. Pada kasus ini dilakukan penempatan pasak ke dalam saluran akar untuk memperkuat dinding saluran akar tanpa mengurangi yang dinding saluran akar yang sudah tipis.

\section{KESIMPULAN}

Apeksifikasi merupakan prosedur yang biasa digunakan untuk gigi permanen yang mengalami trauma dengan kondisi gigi non vital dan apikal yang belum menutup secara sempurna. MTA merupakan alternatif pilihan terbaik untuk proses apeksifikasi yang bertindak sebagai apical plug dan penyembuhan tanpa menunggu pembentukan apical calcific barier sehingga mempersingkat waktu kunjungan pasien dengan langsung dilakukan pengisian saluran akar dan dibuatkan restorasi akhir untuk mencegah fraktur serta mengurangi paparan radiasi antar kunjungan.

\section{DAFTAR PUSTAKA}

1. Caliskan KM, Turkun M, Turkey IWa. Periapikal repair and apical closure of a pulpless tooth using calcium hydroxide. Oral Surg Oral Med Oral Pathol Oral Radiol Endod. 1997; 84: 683 $-687$. 
2. Navageni NB, Umashankara KV, Radhika NB, Manjunath $\mathrm{S}$. Successful closure of the root apex in non vital permanent incisors with wide open apices using single calcium hydroxide dressing-Report of 2 cases. J Clin Exp Dent. 2010; 2(1): 26 - 29.

3. Viddyasagar $M$, Choudhari $S$, Raurale $A$, Dahapute $S$. Apexification and apexogenesis - a case report. IJCD. 2010; 1(3): 52 - 54.

4. Cohen S, Hargreaves, KM. Treatment of the Nonvital Pulp. Dalam path way of the pulp. Cohen, S, Hargreaves, KM, Edisi Ke 9. Mosby, Inc, an affiliate of Elsivier Inc; 2006. 620 - 874.

5. Torabinejad $M$, Walton RE. Protecting the pulp preserving the apex. Dalam endodontics principles and practice. Edisi Ke 4. St. Louis, Missouri; 2009. 29 - 37.

6. Grossman LI, Oliet S, Del Rio CE. IImu endodontic dalam praktek (Endodontice Pratice). Alih bahasa Abyono R. Penyunting Suryo S. Edisi ke 11. Jakarta EGC; 1995. 121 $-125$.

7. Webber RT. Apexogenesis versus Apexification. Dental Clinics of North America. 1984; 28(4): 667 - 669.

8. Frank Al. Theray for the divergent pulpess tooth by continued apical formation. J Am Dent Assoc. 1966; 72 : 87 - 93.

9. Bremann LH, Blanco L, Cohen. Treatment options for open apex that failed to revascularize. Dalam A Clinical Guide to Dental Traumatology. Gutmann, JL, Dumsha, TC, lovdahl, PE, Problem Solving Vital Pulp Therapy Including the Management of the Incompletely Formed Root Apex. Dalam Problem Solving in Endodontics. Prevention Identification, and Management. Edisi Ke 4. Mosby, St Louis Missouri; 2006. 72 - 84.

10. Simon S, Rilliard F, Berdal A, Machtou P. The use of mineral trioxide aggregate in one- visit apexification treatment: a prospective study. Int Endod J. 2007; 40: 186 - 197.

11. Camileri J, Montesin FE, Brady K, Sweeney R, Curtis RV, Pitt Ford TR. The constitution of mineral trioxide aggregate Den Mater. 2005; 21: $731-738$.

12. Duarte MAH, de Oliveria Demarchi ACC, Yamashita JC, Kuga MC, de Campos Fraga S. pH and calcium ion release of two rootand filling materials. Oral Surg Oral Med Oral Patho Oral Radio Endod. 2003; 95: 345 - 347.

13. Frindland $M$, Rasado R. MTA solubility a long term study. J Endod. 2005; 31: 376 - 379.

14. Maroto M, Barberia E, Planelis P, Vera V. Treatment of a non-vital immature incisor with mineral trioxide aggreate (MTA). Dent Traumatol. 2003; 19: $165-169$.

15. El-Meligy AO, Avery DR. Comparison of apexification with mineral trioxide aggregate and calsium hydroxide. Pediatric Dentisry. 2006; 28: 248 - 253.

16. Shabahang $S$, Torabinejad M. Treatment of teeth with open apices using mineral trioxide aggregate Pract. Periodontics Aesthet Dent. 2000; 12: $315-320$.

17. Tittle K, Farley J, Linkhart T, Torabinejad M. Apical closure induction using bone growth factors and mineral trioxide aggregate. JOE. 1996; 22: 198.

18. Steinig Th, Regan JD, Gutmann JL. The use and predictable placement of mineral trioxide aggregate in one-visit apexification case. Aus Endod J. 2003: 29: 34 - 42.

19. Keiser K, Johnnson CC, Tipton DA. Cyctotoxicity of mineral trioxide aggregate using human periodontal ligament fibroblasts. J Endod. 2002; 26: 288 - 291.

20. Apaydin E, Shabahang S, Torabinejad M. Hard-tissue healing after application of fresh or set MTA as root-end filling material. J Endod. 2004; 30: 21 - 24.

21. Shabahang $S$, Torabinejad M, Boyne PP, Abedi HR, McMillan PA. Comparative study of root end induction using osteogenic protein-1, calcium hydroxide and mineral trioxide aggregate in dogs. J Endod. 1999; 25: 1 - 5.

22. Al-Hzalmik, Naghsbandi J, Oglesby S, Simon $\mathrm{JH}$, Rotstein I. Human saliva penetration 
Maj Ked Gi Ind. Agustus 2016; 2(2): 101 - 108

ISSN 2460-0164 (print)

ISSN 2442-2576 (online)

of root canal obstrurated with two types of mineral trioxide aggregate cement. J Endod. 2005; 31: 453 - 456.

23. Sjorgen U, Figdor D, Spangberg L, Sundqvist G. The antimicrobial effect of calcium hydroxide as a short term intracanal dressing. Int endod J. 1991; 24: 119 - 125.

24. Lawley GR, Scindler WG, Walker WA, Kolodrubetz D. Evaluation of ultrasonically placed mta and fracture resistance with intra canal composite in a model of apexification. $\mathrm{J}$ Endod. 2004; 30: 167 - 172. 